\title{
Justification, Denial, and "Terraforming": Three Theological-Exegetical Models
}

Amit Kula

\section{Introduction}

The disparity between human intellect and divine providence ${ }^{1}$ has always been the basis for speculation and intense religious ferment. ${ }^{2}$ The belief in the goodness of God, His omnipotence, and His rectitude lies at the foundation of religious consciousness. ${ }^{3}$ This belief is challenged by the contrasting picture that emerges, as perceived by human intellect, from the realities of life and history, as well as from the Written Torah and oral traditions.

While the theological questions about how God manages the world have been explicitly discussed in the writings of Jewish thinkers, the question of the "correct" exegetical method has only recently merited specific and serious discussion. In my journey along the path of the Torah as it has unfolded over the generations, linking together human efforts to understand the word of God, I have discovered the value of comparing and contrasting the explanations of divine providence with exegetes' answers throughout the generations to the question of the correct method of interpreting the Bible. This article will attempt to delineate the principal approaches to these questions by labeling them, with emphasis on one little known approach.

He does not, or cannot, alienate himself from the reality in which he lives-its physical form, cultural foundations and ethical principles. His response comes from 
where he is. Sometimes he will provide a theological justification in harsh words (beginning with the words: "It is not possible that God...") and sometimes in soft words ("God seeks the partnership of man"), but usually he simply interprets and acts. His response comes from an unqualified belief in God. Out of dedication to this belief, he must, as one faithful to God, remove the impediments and the stains appearing occasionally on the face of the great sun.

Sometimes he wonders who filled his heart with the urge to draw near to his tempestuous surroundings and did not relieve him of this desire. He knows that God abides in the mist, but his heart tells him that he has to follow his first teacher: "Moses approached the thick cloud where God was" (Exod. 20:18).

\section{Providence and Human Endeavor}

The dilemma of the existence of evil in God's world, which ought to be the best of all possible worlds, and the collective solutions to the problem, is a central theme in the field of Jewish philosophy. ${ }^{4}$ Nachmanides describes the crux of the problem thus: "There is something painful and worrying which in itself, in every generation, leads many to outright heresy-it is the appearance of injustice in the world, the suffering of the righteous, and the prosperity of the wicked." 5

The traditional responses to this question fall between two extremes that can be identified with the two approaches presented in the book of Job. One approach, generally understood to be the position of Job's friends, is that human suffering is usually the result of sin and can always be justified. A person's efforts should, therefore, be directed toward revealing the righteousness in the judgments of "a faithful God, never false" (Deut. 32:4). There are various ways of justifying God's judgments. The most common way of explaining suffering is as the expiation for sin. According to this approach, the "righteous" person is not in fact righteous; either he has hidden sins, or is not entirely righteous. ${ }^{6}$ Other explanations are that suffering purifies the soul in preparation for the world to come, or that the concepts of good and evil are different than how they appear at first sight. ${ }^{7}$

The esoteric nature of the conclusion of the book of Job has led some commentators to argue that the alternative approach entails denying the validity of the question. ${ }^{8}$ This form of denial perhaps causes the repression of angst over the disparity between ideals and reality. ${ }^{9}$ The declaration that the 
greatness of God precludes questioning His way of ruling the world, or that the question itself is beyond human comprehension, can be found both in commentaries on Job and in a variety of philosophical responses to this question throughout the generations. ${ }^{10}$

There is, however, a third option, according to which the response to suffering is not static or objective, but is rather to be found within the heart and mind of the suffering individual. It is possible to see the "happy ending" of the book of Job as the outcome of a human decision taken by those involved in this drama not to stand aloof, not to judge or complain, but, instead, to take responsibility for righting wrong. This, in turn, brought about God's blessing for the renewal of good fortune:

Eliphaz the Temanite and Bildad the Shuhite and Zophar the Naamathite went and did as the Lord had told them, and the Lord showed favor to Job. The Lord restored Job's fortunes when he prayed on behalf of his friends, and the Lord gave Job twice what he had before. All his brothers and sisters and all his former friends came to him and had a meal with him in his house. They consoled and comforted him for all the misfortune that the Lord had brought upon him. Each gave him one kesitah and each one gold ring. Thus the Lord blessed the latter years of Job's life more than the former (Job 42:9-12).

Job's friends apologize to him. He does not bear a grudge and prays for them. All his relatives, who had previously rejected him, repent and commiserate with him. They take responsibility and establish a fund to help him restore his property and resume his former life. ${ }^{11}$ God's blessing accompanies this human act, extends it, and enhances it.

There is an allusion to this approach in the closing words of The Guide of the Perplexed. ${ }^{12}$ The ultimate purpose of life, according to Maimonides, is to know God and to cleave to him, "that he understandeth, and knoweth Me" (Jer. 9:23). Judaism innovated here by extending the parameters of divinity: expanding the definition of knowledge of God to include the divine attributes, deeds, and impact on earth, and the ways of His providence:

For when explaining in this verse the noblest ends, he does not limit them only to the apprehension of Him, may He be exalted. ... But he says that one should glory in the apprehension of Myself and in the knowledge of My attributes, by which he means His actions. ... In this verse he makes 
it clear to us that those actions that ought to be known and imitated are loving-kindness, judgment, and righteousness. He adds another corroborative notion through saying, in the earth — this being a pivot of the Law. For matters are not as the overbold opine who think that His providence, may He be exalted, terminates at the sphere of the moon and that the earth and that which is in it are neglected: The Lord hath forsaken the earth. Rather is it as has been made clear to us by the Master of those who know: That the earth is the Lord's. He means to say that His providence also extends over the earth in the way that corresponds to what the latter is, just as His providence extends over the heavens in the way that corresponds to what they are. This is what he says: That I am the Lord who exercises loving-kindness, judgment, and righteousness, in the earth. Then he completes the notion by saying: For in these things I delight, saith the Lord. He means that it is My purpose that there should come from you loving-kindness, righteousness, and judgment in the earth in the way we have explained with regard to the thirteen attributes: namely, that the purpose should be assimilation to them and that this should be our way of life. ${ }^{13}$

These words express the idea that divine providence, including both mercy and judgment, is actualized and applied by those who are devoted to him and follow his ways. ${ }^{14}$ According to this approach, each individual is responsible for the welfare of the world. Each person must fight evil, do justice, and build a world of loving-kindness. When one does so, the purpose of the Creator is revealed: his thirteen attributes are revealed by human action (among other factors). In our generation, there is a growing trend to divert energy from justifying God's judgments to accepting human responsibility ${ }^{15}$ by understanding suffering as an impetus to fix the world ${ }^{16}$ — and, perhaps, as the reason for suffering in the first place.

I will call the first approach to human suffering (the belief in divine providence) "justification," the second approach (in its various forms) "denial” or "repression,"17 and the third approach "terraforming."

This last term requires explanation. Terraforming can be defined as the act of altering the environment of another planet to make it compatible with the conditions of life on Earth and thus capable of supporting human life. In this article, I have borrowed the term to describe creative human activity, whether in nature, society, or biblical exegesis, intended to accommodate the inclusion of faith-based values in modern life. In this context, "terraforming" refers to taking the celestial Torah, with its infinite range of meaning, and giving it a concrete 
worldly meaning: bringing the Torah from heaven to earth. The term connotes a heroic act from science fiction; it is doubtful that such a project will ever be feasible. Terraforming raises ethical concerns regarding hubris: "Who are you, small, insignificant man, to interfere with the cosmic order without being able to see the whole picture-are you God?" 18 This concept is very relevant to the method of exegesis that mediates between the human and the divine.

Needless to say, these titles are not intended to indicate judgment or preference. The purpose of the labeling is to assist us in categorizing the approaches. The field of psychology, from which some of the names are derived, teaches us that every personal attribute plays a positive role in a healthy personality; personal religious awareness is also composed of many conflicting aspects. Likewise, it is understood that it is not always easy to distinguish between various solutions, and sometimes integrated approaches or interpretations develop. Nonetheless, I have found that these distinctions are instrumental in systematizing the understanding and analysis of theological questions, especially in the area of exegesis. ${ }^{19}$

\section{Exegesis}

In recent years, the increased awareness of the presence of the reader and his or her role in understanding the text has enhanced the importance of the study of hermeneutics. These studies have become a subject of discussion among Torah scholars, especially those involved in academic research. ${ }^{20}$

Faith-based scholarship has redefined old questions about the conflicts between modern science and the biblical narrative (including the more recent and quite exceptional confrontation with biblical criticism) while raising new questions related to core values of contemporary culture. We can now find studies about the Jewish approach to liberty, equality, and the value of human life. Many studies have been conducted investigating attitudes toward the other: non-Jews, ${ }^{21}$ the disabled, ${ }^{22}$ and, most extensively, the status of women. ${ }^{23}$

A religious man-for whom the validity of our Law has become established in his soul and has become actual in his belief-such a man being perfect in his religion and character, and having studied the sciences of the philosophers and come to know what they signify - where will he turn?

His mind is occupied with foreign cultures, and secular values and ethics have entered his heart. When he reads the Torah he finds verses that do not conform to 
principles of science, culture, and morality, and he begins to doubt and to become perplexed: Should he follow his reason and the values he believes in and reject the simple meaning of the verses in God's Torah? By doing so he wounds his soul, relinquishes a precious treasure, and cuts the thread of life.

Perhaps he will change his opinions in light of the verses and concede to what appears to be the opinion of the giver of the Torah? In that case he will feel as though he has betrayed his values, and he will cause himself damage and loss, and will be left with a feeling of pain and unease, and will not cease to suffer from heartache and great perplexity. ${ }^{24}$

Exegetical questions take on special meaning with regard to sacred texts because they are usually accompanied by rigid traditions that restrict the freedom of interpretation. ${ }^{25}$ Nevertheless, there is an exegetical Jewish tradition that has persistently called for creativity and innovation. ${ }^{26}$ In this exegetical tradition, this tension is reflected in the question of the transmission of the Oral Law and its sources. ${ }^{27}$

Classical rabbinic literature reflects a high level of awareness of ethical difficulties in the Bible in general, and in the commandments specifically. A good example of this, the subject of much scholarly analysis, is the commandment concerning "the rebellious son" (Deut. 21:18-21). The rabbinic interpretations of this verse reflect the three exegetical traditions mentioned above. ${ }^{28}$

The obligation of the boy's parents to have him executed for disobedience was perceived by the sages as totally unreasonable for various reasons. A midrash halakhah (rabbinic legal commentary) presents the question in the following way: "Is he to be stoned for eating a tartemar [approximately 200 grams] of meat and drinking half a $\log$ [approximately half a liter] of wine?" 29 There are three responses to this question. The first response considers the Torah's assumption to be that the rebellious son is destined to become a murderer. ${ }^{30}$ This is an apologetic interpretation that assumes the simple meaning of the Torah, the demand for a severe punishment for the rebellious son, is correct. Its efforts are directed to making the profundity of divine judgment accessible to human understanding, while, at the same time, justifying the severity of the punishment by revealing the underlying argument or reasoning that is not immediately apparent.

The second approach rejects the possibility of discovering the rationale behind the law and denies the importance of human rationalization altogether. ${ }^{31}$ According to this approach, it is both impossible and 
unnecessary to reconcile a divine imperative with human reason. This position advocates submission to divine authority, which is the source of the imperative to observe the commandments, traditionally perceived as the decrees of an absolute monarch. ${ }^{32}$

The third approach, also expressed in this context, recognizes the sanctity of the Bible and its undisputed authority, yet does not acquiesce to what appears to be an absolute decree nor adapt itself to apologetic explanations. It takes a stand and affirms the "impossible." This approach is exemplified in the Babylonian Talmud (tractate Sanhedrin 71a): "Rabbi Simeon said: 'Because he ate a tartemar of meat and drank half a $\log$ of Italian wine, his parents bring him to be executed? There never was such a case and there never will be. If so, why was it written? Interpret it and be rewarded."

The inability to accept the commandment of the rebellious son, for whatever reason, brings the commentator to a significant conclusion: this commandment will never be fulfilled, nor was there ever any intention that it should be fulfilled. ${ }^{33}$ Why then was it written? To be interpreted: "Interpret it and be rewarded." 34 The sage, whether by means of extra-contextual interpretation or by restrictive exegesis, neutralizes the commandment and renders it palatable. ${ }^{35}$

There is reason to believe that one of the sources of this exegetical tradition is the school of Rabbi Akiva. He initiated an approach to religion that taught that the actions of people are greater than the actions of God. Humankind is expected to better the material world created by God, in both its physical and social aspects. ${ }^{36}$ Similarly, in the field of Torah study, Rabbi Akiva ascribed considerable significance to the creative power and mental alacrity of the student. The breadth of his interpretation of the Torah astonished and excited his colleagues and teachers alike. ${ }^{37}$ A good example of his exegetical approach can be seen in the following passage: "And concerning her who is in menstrual infirmity' (Lev. 15:33) — The early sages said that when she is in a state of menstrual impurity, she should not put on makeup until she immerses in water, until Rabbi Akiva came and taught that this could cause her husband to dislike her and wish to divorce her. How then do we understand 'and concerning her who is in menstrual infirmity'?-She is in menstrual impurity until she immerses in water." 38

Rabbi Akiva's deviation from the established interpretation was propelled by an ethical consideration (marital harmony) rather than a philological preference. He gave expression thereby to a seminal principle of his approach: the commentator has the responsibility to provide the best possible 
interpretation that also takes into account ethical considerations, according to his understanding and perspective-in other words, terraforming.

The following discussion provides another good example of terraforming. According to the biblical narrative, Esther was taken to Ahasuerus's palace and, after a selection process, was chosen by him to be his wife and the queen of Persia and Media. Although this chain of events led to the salvation of the Jews, traditional texts reflect dismay at the marriage of a Jewish woman to a nonJewish king. ${ }^{39}$ Never before had a biblical heroine been doomed to such a cruel and demeaning fate. ${ }^{40}$ This is the background to a remarkable commentary that appears in the Zohar:

If it seems as though Ahasuerus had marital relations with Esther, because they lived in the same house-Heaven forbid! "Esther" is derived from the word seter [concealment]. She hid from Ahasuerus and a demon was put in her place, and she returned to Mordechai's embrace. Similarly, God saved Sarah, and even her jewelry, from Pharaoh. For every piece of jewelry he touched, God struck him; how much more would he have received if he had touched her body, even her little finger. God did not allow him to get near her. ${ }^{41}$

The commentator will not leave the study hall as long as his sister, our sister, is being defiled by the Persian king. His heart, his religious perspective, and his feeling of Jewish solidarity compel him to rescue her. He uses all available means - that is, exegesis - to save Esther from impurity and disgrace. ${ }^{42}$ It is the responsibility of senior Torah scholars to ensure that the biblical narrative contains the best possible story and that undesirable content is weeded out by exegetical means.

This example clarifies a modern aspect of the parameters of terraforming exegesis. The increasing awareness of the role of the commentator clarifies the boundary between peshat (contextual interpretation) and derash (homily). In our time, the role of derash as the primary means of terraforming has declined because homiletical interpretation has become difficult to accept. Today's students prefer the straightforward meaning of the text that makes no adventurous assumptions, does not offer unusual interpretations of the written word, and does not add to what is explicitly stated aside from the obvious.

In this light, we must clarify the distinction between contemporary terraforming commentary and apologetic commentary. Apologetic exegetes stretch their intellectual abilities in order to justify the simple language of the text and 
the content of the commandments. After the apologetics, the verses remain as if untouched by human hands.

Terraforming exegesis, however, deviates from the straightforward or accepted interpretation, and proposes an alternate meaning compatible with the values and worldview of the commentator. The terraformer is compelled to interpret in this way because he is inherently limited by his own perspective. ${ }^{43}$ Terraforming exegesis has recently become popular once again. Thirty years ago, biblical scholars committed to Jewish tradition complained that "Judaism has not provided fertile ground for the development of a theologian cognizant of both traditional Jewish sources and contemporary critical biblical scholarship." ${ }^{44}$ These words were a call to Jewish biblical scholars to dedicate themselves to serving the community (an approach already taken by certain Christian scholars), by producing academic research relevant to Judaism and Jewish life. It is doubtful that this call was heeded by many scholars. However, in subsequent years the development of the analytical study of the Bible has produced many articles and commentaries that meet the challenge of integrating modern knowledge and culture into a system grounded on deep-seated, traditional beliefs. ${ }^{45}$ A significant number of these works can be defined as "terraforming." 46

\section{Endnotes}

1. This disparity can be found in the Bible, beginning with Cain's appeal to God (Gen. 4:1314 and Rashi's commentary there); continuing with Abraham's questions (Gen. 15:8, Babylonian Talmud, tractate Nedarim 32a, and the commentary of the Kli Yakar on this verse); Moses' desire to know the essence of God (Exod. 33:18 and Maimonides, The Guide of the Perplexed, 1:54); the anger of the prophets (Josh. 7:7, 1 Sam. 15:11); and ending with such straightforward questions and reflections as: "Shall not the Judge of all the earth deal justly?" (Gen. 18:25); "Why does the way of the wicked prosper?” (Jer. 12:1); and "Why do You countenance treachery, and stand by idle while the one in the wrong devours the one in the right?" (Hab. 1:13).

2. It would appear that the root of this distress was expressed in the "acute vagueness" of the Ari as "the empty void." The dichotomy between the creator and his creation is impossible according to the definitions of both and this is the origin of all the dilemmas. See Etz Ha-Hayyim, part 1, sec. 2. See also Moshe Hallamish, An Introduction to the Kabbalah, trans. Ruth Bar-Ilan and Ora Wiskind-Elper (Albany: State University of New York Press, 1999), 197-201.

3. This theological assumption of God's goodness and the dilemmas it creates were clarified by Rabbi Moshe Hayyim Luzzatto in his books. See Kalah Pithei Hohma (138 Openings of Wisdom), trans. Avraham Greenbaum (Jerusalem: Azamra, 2005), 1-15. Derekh ha-Shem (The Way of God), trans. Aryeh Kaplan (Jerusalem: Feldheim, 1977), 31-87.

4. An attempt to present a comprehensive picture of the development of theodicy in Judaism can be found in Shalom Rosenberg, Good and Evil in Jewish Thought, trans. John Glucker (Tel Aviv: MOD Books, 1989); and Eliezer Schweid, Le-Hagid Ki Yashar ha-Shem: Hazdakat Elohim 
be-Mahshevet Yisrael me-Tekufat Ha-Mikra ve-ad Shpinoza ["To Declare that God is Upright": Theodicy in Jewish thought from the Bible to Spinoza] (Bat-Yam: Tag Publications, 1994). On the kabbalists' discussion of this subject, see Gershom Scholem, Pirkei Yesod be-Havanat ha-Kabalah u-Smaleyah [Elements of the Kabbalah and its symbolism], trans. Yosef Ben-Shlomo (Jerusalem: Mosad Bialik, 1980), 189-212; Gershom Scholem, Kabbalah (Jerusalem: Keter, 1974), 122-128; Isaiah Tishbi, The Wisdom of the Zohar, trans. David Goldstein (Oxford: Oxford University Press, 1989), 2:447-508; and Isaiah Tishby, Torat ha-Ra ve-ha-Kelipah be-Kabalat ha-Ari [The doctrine of evil and the kelipah in Lurianic kabbalism] (Jerusalem: Magnes, 1994), 13-20. A summary of the various positions in Jewish philosophy in the Middle Ages can be found in Hayyim Kreisel, "Tzadik ve-Ra Lo be-Pilosofia ha-Yehudit be-Yimei ha-Benayim" [The suffering of the righteous in Jewish philosophy in the Middle Ages], Daat 19 (1987): 17-29. Further information can be found in Ehud Ben-Or, "Modelim le-Havanat ha-Ra be-Moreh Nevuhim" [Models for understanding evil in The Guide of the Perplexed], Iyyun: The Jerusalem Philosophical Quarterly 34 (1985): 3-33; and, also Dror Ehrlich, "Ba'ayat ha-Ra be-Sefer ha-Ikkarim le-Rabbi Yosef Albo" [The problem of evil in the Sefer Ha-Ikkarim of Rabbi Joseph Albo], Péamim: Studies in Oriental Jewry 116 (2008): 117-142. A discussion of this question in Jewish thought in the modern period can be found in Yehuda Gellman, "Ha-Ra ve-Tziduko be-Mishnat Ha-Rav Kook" [Evil and its justification in the thought of Rav Kook], Daat 19 (1987): 145-155. In addition, much thought has been devoted to the subject in connection to the Holocaust. See, for e.g., Eliezer Berkovits, Faith after the Holocaust (New York: KTAV, 1973); Eliezer Schweid, Bein Hurban le-Yishua: Teguvot Hagut Haredit le-Shoah be-Zemana [From destruction to redemption: Haredi responses to the Holocaust] (Tel Aviv: Hakibbutz Hameuhad, 1995). An analysis of the positions on the edge of the postmodern world can be found in Gili Zivan, "Emunah Nokhah Shekhol ve-Ovdan" [Faith in the face of loss and bereavement], in ed. Moshe Halbertal et al., Al ha-Emunah [On faith] (Jerusalem: Keter, 2005), 490-511. A unique perspective on this subject can be found in the collection of articles in Baruch Kahana, Chayuta Deutsch, Ronny Redman, ed., Hidat ha-Yisurim [The enigma of suffering] (Tel Aviv: Miskal, 2012).

5. Perush le-Sefer Iyov [Commentary on the book of Job], in ed. Chaim Dov Chavel, Kitvei Rabenu Moshe ben Nahman [The writings of Nachmanides] (Jerusalem: Mosad Harav Kook, 1963), 1:19.

6. See Babylonian Talmud, tractate Berakhot 5b ("Who can suspect the Holy One blessed be He of judging unjustly?”) and the Tosafot commentary, s.v. dina. See also tractate Berakhot 7a: "The righteous man who suffers—-he is not entirely righteous."

7. Saadia Gaon, The Book of Beliefs and Opinions, trans. Samuel Rosenblatt (New Haven: Yale University Press, 1948), 209-221. On the difficulties of this approach, see Haggai Dagan, "Kol ha-Teodikiot Miyutarot Hen: Shlomo Maimon al Teoditza" ["All theodicy is superfluous": Solomon Maimon on theodicy], Tarbiz 70 (2001): 587-600.

8. See, e.g., Y. M. Rosenberg, "Ha-Im Kibel Iyov Teshuva le-Ta’anotav be-Ma'aneh HaShem?" [Did Job receive divine responses to his arguments?], Be-Sdeh Hemed 2-3 (2002): 25-32: "His capitulation was the result of a deep understanding of the meaning of the human encounter with God ... therefore there is no ground to even question why the righteous suffer and the wicked prosper." Although the article explores other angles, the author nonetheless felt it necessary to add a statement of denial.

9. Moshe Greenberg, "Hirhurim al ha-Teologia shel Iyov" [Thoughts on the theology of Job], Hagut be-Mikra 4 (1984): 55-62. Greenberg's argument is a kind of repression and denial of anguish through indecision, while acknowledging our inability to answer the question: "While the realistic believer does not simplistically assume the ethical causality of God 
neither does he deny it completely ... we can understand neither the peace of the wicked nor the suffering of the righteous."

10. The belief, found in classical rabbinic literature, that there is no reward in this world for fulfilling the commandments can be seen as a way of denying the validity of the question. A harsh formulation of this approach appears in Babylonian Talmud, tractate Kiddushin 39b: "One whose good deeds outnumber his sins is punished, and it is as if he burnt the entire Torah, not leaving even a single letter. One whose sins outnumber his good deeds is rewarded, and it is as if he observed the entire Torah, not omitting even a single letter.... There is no reward for the commandments in this world." The philosophical coda to this discussion declares the apparent lack of justice in the world.

11. Joseph B. Soloveitchik, Kol Dodi Dofek—Listen My Beloved Knocks, trans. David Z. Gordon (New York: Yeshiva University, 2006), 13-19.

12. The commentators on The Guide differed with regard to the explanation of the relationship between the divine attributes, providence, and devotion to God.

13. Maimonides, The Guide of the Perplexed, 3:54. This passage is a running commentary on Jeremiah 9:23: "But only in this should one glory: In his earnest devotion to Me. For I the Lord act with kindness, Justice, and equity in the world; For in these I delight—-declares the Lord." Maimonides understands this verse to mean that the goal of attaining knowledge of God is more important than the desire for great wealth or spiritual perfection.

14. See the commentaries, including Eliezer Berkovits, "Ahrayut ha-Adam ve-Hashgaha beHistoria" [The responsibility of man and Providence in history], in Hevra ve-Historia [Society and history], ed. Yehezkel Cohen (Jerusalem: Ministry of Education, 1980), 513-519.

15. See, e.g., Rabbi Mordechai Piron, "She'elat ha-Ra ha-Hevrati ve-ha-Musari ba-Yakum" [The question of social and ethical evil in the universe], in Minha le-Menahem [An offering to Menahem], ed. Hana Amit et al. (Bnei Brak: Hakibbutz Hameuchad, 2008), 19-29. The article opens with the theological question and extends its conclusions to the human responsibility to "perceive the divine essence in man."

16. See Rabbi Abraham Isaac Ha-Kohen Kook, Orot ha-Kodesh (Jerusalem: Mosad Harav Kook, 1963-1964), 3:70: "No redemption is truly complete unless the redeemed labored with his own hands for its arrival." The approach presented in the treatise can facilitate the development of a religious language in continuity with Jewish tradition, and give religious meaning to an idea whose revolutionary essence is capable of precipitating a break with faith and its language, and their subsequent loss. See Ze'ev Levi, “Teoditza” [Theodicy], Moed 17 (2007): 91-103. At the end of this article, he mentions the idea, which he ascribes to several thinkers, including Buber and Levinas, that, instead of ultimately justifying the acts of God, we should be fostering hope and productivity that will make the world a better place and eradicate evil and wickedness. Humanity must work to realize the desired good, not wait for it passively. Note the difference between the style and purpose of the two articles. It is worth reflecting on the possibility of combining these positions with the opinion currently expressed within the rabbinic world, which limits the scope of divine providence. On this point, see Rabbi Hayyim David HaLevy, Aseh Lekha Rav [Get yourself a rabbi] (Tel Aviv: The Committee for the Publication of the Works of Rabbi HaLevy, 1989), 9:278-288; and Rabbi Shemuel Ariel, "Mashmayuot Emuniot u-Ma'asiyot be-Sugiyot ha-Hashgacha" [Faith-based and practical implications of questions of providence], Tzohar 31 (2008): 115-130.

17. This approach involves a form of willful submission before the greatness of God and the rejection of an apologetic approach to theodicy. In certain cases, the denial stems from an inability to cope with the problem of divine providence and the subsequent desire to eradicate it. 
18. On this point, see D. MacNiven, "Environmental Ethics and Planetary Engineering," British Interplanetary Society 48 (1995): 441-443.

19. The three exegetical voices mentioned here are paralleled by the three stages of transcendent consciousness posited by Rabbi Soloveitchik. See Joseph B. Soloveitchik, And From There You Shall Seek, trans. Naomi Goldblum (Jersey City: Ktav, 2008), 149-150. The first stage, escape and fear, is slightly similar to denial and repression. The second stage is similar to apologetics while the third stage has something in common with terraforming.

20. What is peshat? This question lies at the core of this high-level, multifaceted debate. A discussion of the legitimate boundaries of current exegesis and related issues can be found in various issues of the journal Megadim. The article by Rabbi Yaakov Medan, "Megilat Bat Sheva" [The scroll of Bathsheba], Megadim 18 (1993): 67-167, generated a chain of critical responses that analyzed the issue from multiple perspectives. See Itamar Warhaftig, "Parasht David ve-Bat Sheva" [David and Bathsheba], Megadim 22 (1994): 84-90, and Rabbi Medan's response in that same issue: Rabbi Yehuda Brandes, "Bemai Kamipalgi" [What is this argument about?], Megadim 26 (1996): 107-127; Rabbi Yaakov Medan, "Eich Lelamed Senagoria al David" [How can one defend David?], Megadim 26 (1996): 129-134; and Avraham Walfish, "Be-ha Kamipalgi!" [This is what the argument is about!], Megadim 28 (1998): 87-103; Rabbi Yaakov Medan, "Lo Rak ba-Ha” [Not only about that], Megadim 28 (1998): 105-106; Rabbi Yehuda Brandes, "Hakdamot Hekhrahiot le-Kol Perush” [Essential introductions to every commentary], Megadim 28 (1998): 107-120; Rivka Raviv, "Be-Gvulotav shel ha-Perush ha-Legitimi" [The boundaries of legitimate interpretation], Megadim 31 (2000): 115-117; Avraham Walfish, "Ha-Kalut ha-Bilti Nisbelet she ha-Parshanut” [The unbearable lightness of exegesis], Megadim 31 (2000): 119-126.

21. See the fundamental debate between Yosef Ahituv and Rabbi Avichai Rontzki discussed, in part, in Meimad 16 (1999): 16-20.

22. See, e.g., Moshe Rachimi, ed., Ve-Hai Ahikha Imakh [Enable your brother to live with you] (Elkana: Orot College, 2011), especially the article by Aviad Hacohen, "Kol Ish Asher Bo Mum lo Yikarev?" [No one who has a defect shall be qualified?], 51-77.

23. See, e.g., the articles by Tamar Ross, including "Hashlakhot ha-Feminism al Teologia Yehudit Ortodoksit" [The impact of feminism on Orthodox Jewish theology], in Rav Tarbutiot be-Medina Demokratit ve-Yehudit [Multiculturalism in a democratic and Jewish state], ed. Menachem Mautner et al. (Tel Aviv: Ramot, 1998), 443-464; and Amit Kula, "Hirhurim al Ma'amad ha-Isha be-Mesoret ha-Yehudit be-Re'i Zmanenu” [Reflections on the status of women in Jewish tradition from a modern perspective], in Ha-Isha [Woman], ed. Zeev Karov (Jerusalem: El Ami, 2000), 23-34.

24. Based on The Guide of the Perplexed, 5. See also Rabbi Abraham Isaac Ha-Kohen Kook, Shmonah Kvaztim (Jerusalem, 1999), 3:184. One can argue that being torn between two worlds is the ideal state, or at least the fate, of the believer in the postmodern world. However, it is important to distinguish between real conflict and the ideal state of latent tension. A permanent state of crisis is a form of denial without repression and perhaps even an evasion of duty and immediate responsibilities (see further below).

25. "But in the case of texts which are sacred, properly speaking, one cannot allow oneself too much license, as there is usually a religious authority and tradition that claims to hold the key to its interpretation." Umberto Eco, Interpretation and Over-Interpretation: World, History, Texts, ed. Stefan Collini (Cambridge: Cambridge University Press, 1992), 169. "The commentary of an exegete who interprets a verse in a way that is contrary to universally accepted halakhah is to be rejected because he can be considered as one who disagrees with the Oral Law that is binding upon every Jew." Moshe Arend, "Al Peshuto shel Mikra 
u-Midrash Halakha" [The simple meaning of the text and midrash halakhah], Iyyunei Mikra u-Parshnut [Studies in Bible and exegesis] 8 (2008): 23. See also p. 26, and the reference to Rabbi Kasher there. This statement, which appears to be describing traditional Jewish exegesis, includes a normative declaration about the present ("binding upon every Jew"). "And furthermore, there is the fear of opening channels of critical commentary that might weaken religious belief." Eran Viezel, "Hibur ha-Torah ve-Hitgabshut ha-Nusaḥ shela le-Da’at Kahane: Perek be-Demuto shel Bikoret ha-Mikra ha-Yehudit-Ortodoksit be-Mizrah Eropa be-Tekufat ha-Haskala" [The composition of the Torah and formation of its text according to Kahane: A study in the nature of Orthodox Jewish biblical criticism in Eastern Europe in the period of the Haskalah], in "Leshev Peshuto shel Mikra": Asufat Mekharim be-Parshanut ha-Mikra ["To settle the plain meaning of the verse": Studies in biblical exegesis], ed. Sara Japhet and Eran Viezel (Jerusalem: Mosad Bialik, 2011), 249.

26. In a story found in the Jerusalem Talmud, tractate Sanhedrin $4 \mathrm{~b}$, God declined to render judgment himself in order to leave room for future generations' commentary. See also She'elot u-Teshuvot ha-Radbaz 3:643 [1075]), which states that the Torah is written in a manner intended to allow a wide scope of exegetical options. See also Jerusalem Talmud, tractate Pe'ah 2d: "Even what an advanced student will teach in his master's presence in the future was already said to Moses on Sinai."

27. Should the nature of the Oral Torah be understood as explained by Maimonides in his introduction to his commentary on the Mishnah? (Fred Rosner, trans., Maimonides' Introduction to his Commentary on the Mishnah, [Northvale, NJ: Jason Aaronson, 1995], 7-12.) Or according to the explanation of Rabbi Tzadok Ha-Kohen? (Divrei Sofrim, 38 inter alia). On this question see Avia Hacohen, "Rabbi Tzadok ha-Kohen ve-Hitpathut Torah she-be-al Peh" [Rabbi Tzadok and the development of the Oral Law], Mishlav 35 (2000): 15-25. Or is the nature of the Oral Law as described by Rav Kook? (Orot haTorah, chapter 1:1-2). See also David Halivni, “Torah Shebe'al Peh: Hitgalut o Midrash?” [Oral Law: Revelation or commentary?], in Yosef Da'at: Studies in Modern Jewish History in Honor of Yosef Salmon, ed. Yossi Goldstein (Beer-Sheva: Ben Gurion University, 2010), 129-142. The impact of this debate can be seen in Louis Finkelstein, "Ha-Deah ki Yud Gimel Midot hen Halakha le-Moshe Misinai" [The belief that the thirteen rules were given to Moses on Sinai], in Sefer ha-Zikaron le-Rabbi Shaul Lieberman [Saul Lieberman Memorial Volume], ed. Shamma Friedman (New York: Jewish Theological Seminary of America, 1993), 79-84.

28. Moshe Halbertal, Mahapekhot Parshaniot be-Hithavtan [Interpretative revolutions in the making] (Jerusalem: Magnes, 1997), 43-67.

29. Louis Finkelstein, ed., Sifrei al Sefer Devarim (New York: Jewish Theological Seminary of America, 1969), 253. This question has been expressed in various ways. The diversity of expression is indicative of the multiplicity of difficult aspects of the commandment that did not make sense to the sages, including the disparity between the veniality of the sin and the severity of the punishment, the unlikelihood that parents would facilitate the killing of their son for over-eating, and the restrictive legal conditions (the law applies specifically to an underage boy).

30. This justification appears in two different formulations. Babylonian Talmud, tractate Sanhedrin $72 \mathrm{~b}$ states: "He should die innocent rather than guilty." Midrash Tenaim leDevarim, 21:21 reads "it is better that one soul is lost than that many are lost."

31. The idea that the son is judged on the basis of his future acts of burglary is meant to alleviate the difficulties discussed in the Jerusalem Talmud. See also Halbertal, Mahapekhot, 58.

32. Jerusalem Talmud, tractate Sanhedrin 8a. 
33. See note 36. See also the commentary of the Yad Ramah to Sanhedrin 8a, s.v. keman azla. The Zohar's commentary (3:197b) is also interesting. It portrays Moses voicing the criticism to God, saying: "Leave it be! Is there a father who would do such a thing to his son?"

34. See the commentary of Rav Kook, Iggrot Ra'aya (Jerusalem: Mosad Harav Kook, 1961), 1:305. "It was written for the sake of 'interpret it and be rewarded.' The reward for interpretation is very great because it is the salt that preserves quality by increasing the hatred of evil in all its aspects, and because the act is accomplished through study it does not materialize at all in actuality."

35. Rabbi Yehudah uses the method of restrictive exegesis to deduce from the biblical text that the fulfillment of the commandment is contingent upon an improbable similarity between the parents in voice, appearance, and height (Babylonian Talmud, tractate Sanhedrin 71a). Like Rabbi Shimon, he is one of those who believe that there never was a real case of a "rebellious son." It should be noted that both sages were the students of Rabbi Akiva, while Rabbi Yonatan, the student of Rabbi Yishmael, disagrees with this position and declares: "I saw himself myself and sat on his grave." See also the position of Rabbi Akiva.

36. Babylonian Talmud, tractate Bava Batra 10a: "If your God loves the poor, why does he not feed them? ... So that through them we may be saved from Hell." Midrash Tanhuma, Tazria' 5: "The wicked Turnus Rufus asked Rabbi Akiva: 'Whose deeds are greater, those of God or those of man?' . . Rabbi Akiva brought him stalks of grain and cakes and said that the stalks were made by God while the cakes were made by man." It should be noted that the example of the stalks and the cakes also appears in Midrash Eliyahu Zuta, 2, in relation to the correct method of interpreting the Torah.

37. Mishnah, tractate Sotah 5:1-2: "Rabbi Yehoshua said, 'Who will remove the dirt from your eyes, Rabban Yohanan ben Zakkai? ... Now Akiva your student brings a verse from the Torah to show that ..." Babylonian Talmud, tractate Zevahim 13a: "Akiva, whoever departs from you [i.e., your method of study] is as though he departed from life." See Shmuel Safrai, Rabbi Akiva ben Yosef: Hayyav u-Mishnato [Rabbi Akiva son of Yosef: His life and teachings] (Jerusalem: Mosad Bialik, 1978), 60. This book continues the approach to biblical interpretation formulated by Benjamin De Vries in Toldot ha-Halakha ha-Talmudit [The history of Talmudic law] (Tel Aviv: Tzioni, 1966), 14: "The congregation of Israel, an ethnic group with a high level of religious tension ... the Torah and sacred writings are what determines its character and chart its course, and thus interpreting the Torah is the focus of spiritual life. It is an easy transition from interpretation to homily [me-drisha le-midrash]."

38. Sifra, Metsora', 9,12.

39. This event is the interpretative source for the laws pertaining to commandments for which one must die rather than transgress: "Esther was merely arable soil" (Babylonian Talmud, tractate Sanhedrin 74b). There is deeper bitterness in the words put into Esther's mouth as she voluntarily approaches Ahasuerus: "Until today, [I was with him] out of coercion, and today, willingly. 'And if I am to perish, I shall perish!' Just as I was lost to my father's house, so I am lost to you." (Babylonian Talmud, tractate Megillah 15a, based on Esther 4:16).

40. See Gen.12:17-20 and 20:3-18. In my opinion, Yair Zakovitch was incorrect when he argued that Esther's plight compares favorably with that of other biblical heroines. His commentary ignores the Jewish character of the story and its moral-religious messages: a Jewish woman should not be under the control of a non-Jewish king. Yair Zakovitch, Mikraot be-Eretz ha-Marot [Through the looking-glass: reflection stories in the Bible] (Tel Aviv: Hakibbutz Hameuchad, 1995).

41. Zohar, 3:276a. This is an approximate and partial translation. 
42. I am aware of the fact that the commentator's exegetical difficulty is not related to the historical figure of Esther, the heroine of the book, but to what she represents in his system of esoteric thought-namely, the Shekhinah. However, on this level as well, the author of the Zohar had to construct a terraforming interpretation in order to maintain the awareness of his religious devotion. According to the position of the author/s of the Zohar, the connection between the simple meaning of the biblical story and the messages hidden within it should be self-evident. See Amit Kula, Havaya o lo Haya [(Existential or nonessential: History and literature, religious language, and the nature of deity] (Jerusalem: Hakibbutz Hadati, 2011), 161-164.

43. See Rabbi Aryeh Leib Heller's author's introduction to Ketzavot ha-Hoshen (Jerusalem: Shiloh, 1973): "The Torah was not given to the ministering angels, but to man, who has human understanding. God gave us the Torah, in his great mercy and loving-kindness, according to human understanding, even if it is not true on the level of the separate intelligences.... He gave us the Torah according to human understanding even if it is not true, and if so an original interpretation is entirely original, but it must be true according to human understanding."

44. Moshe Goshen-Gottstein, "Hakhmat Yisrael: Hekher ha-Mikra ve-Teologia Mikrait Yehudit" [The academic study of Judaism: The study of the Bible and Jewish biblical theology], Iyyunei Mikra u-Parshnut [Studies in Bible and exegesis] 1 (1980): 243-255. In a later article ("Teologia Mikrait Yehudit u-Mada Dat ha-Mikra" [Jewish biblical theology and the study of the religion of the Bible], Tarbiz 50 [1981]: 36-64), Goshen-Gottstein distinguishes between the student of religion who preserves the distance required for objectivity, and the theologian who identifies with the subject of his research and is nourished from the same sources as the thinkers of the past. In this article, he deplores the takeover of the study of biblical theology by Protestant scholar-theologians who do not include Jewish theology within the framework of their studies. See Moshe Greenberg, "Hayitakhen Mada Mikra Bikorti Ba'al Ofi Yehudi?" (Is a critical Jewish study of the Bible possible?), Proceedings of the World Congress of Jewish Studies 8 (1981): 95-98.

45. In this context, it is important to note in particular the new developments of the last thirty years. Firstly, the completion of the commentary Da'at Ha-Mikra, on which see Yehuda Keel "Al ha-Tzorekh be-Perush Mesorti-Mada'i al ha-Mikra u-Midotav" [On the need for a traditional-academic commentary on the Bible and its features], Be-Sedeh Hemed 20 (1977): 8-16. To this must be added the dissemination of Rabbi Mordechai Breuer's approach to Bible study, influenced by biblical criticism. On Rabbi Breuer see Yosef Ofer, ed., Shitat ha-Behinot shel ha-Rav Mordechai Breuer [The aspects theory of Rav Mordechai Breuer: articles and responses] (Alon Shvut: Tevunot, 1995); and Adiel Cohen, "Kabbalah as a Shield against the 'Scourge' of Biblical Criticism: A Comparative Analysis of the Torah Commentaries of Elia Benamozegh and Mordecai Breuer," in this volume. The journal of Herzog College Megadim, which has published hundreds of articles, reflects the strengthening of the approach anticipated by the aforementioned scholars.

46. A classic example is Rabbi Yoel Bin Nun, "Ha-Pelug ve-ha-Ahdut: Kefel Ta'ut ve-Helem ha-Galui; Mipnei Mah lo Shalach Yosef (Shaliah) el Aviv?” [The Schism and the unity: A double mistake and the shock of discovery; why didn't Joseph send a message to his father?], Megadim 1 (1986): 21-30. This article aims to find an alternative to understanding Joseph's deeds as an attempt to realize his dreams. The article generated responses in which the subject was reevaluated. The foundations of the new exegetical approach are embedded in the various articles. See the index to articles in Megadim 50 (2009): 242. 
The work of Uriel Simon demands further attention. For the present, see Uriel Simon, Bakesh Shalom u-Radfehu [Seek peace and pursue it] (Tel Aviv: Miskal, 2004), 15. The formation of a readership with similar questions and levels of comprehension, who are the beneficiaries of the process of terraforming, is a process that involves the search for interpretations of the Bible that conform to this group's ethical outlook. For this reason, peshat must be defined in a certain way-in Simon's words, as "meaningful peshat." Uriel Simon ed., Ha-Mikra ve-Anahnnu [The Bible and us] (Ramat Gan: Dvir, 1998), 149-152. See also Uriel Simon, Reading Prophetic Narratives, trans. Lenn J. Schramm (Bloomington: Indiana University Press, 1997), xiv-xvi. In a review article, Baruch Alster attempts to obscure the political agenda (Baruch Alster, "Arakhim be-Peshuto shel Mikra" [Values in the simple meaning of the text], Megadim 48 [2008]: 117-122), although without great success, as can be seen in the article of Rabbi Yaakov Medan (Megadim, 48 [2008]: 123-124). See also Simon's response (ibid., 125-131). Further research on this subject is necessary. 